\title{
Histometric and biochemical properties of the thyroid gland in sheep with high iodine supplementation
}

\author{
Zdeněk Peksa ${ }^{1}$, Jan Trávníček ${ }^{1}$, Roman Konečný ${ }^{1}$, František Jelínek ${ }^{2}$, Hana Dušová ${ }^{1}$, \\ Lucie Hasoňová ${ }^{1}$, Václav Pálka ${ }^{1}$ \\ ${ }^{1}$ University of South Bohemia in České Budějovice, Faculty of Agriculture, \\ Department of Veterinary Sciences and Quality of Products, Ceské Budějovice, Czech Republic \\ ${ }^{2}$ Veterinary Histopathological Laboratory, Prague, Czech Republic
}

Received February 11, 2013

Accepted August 28, 2013

\begin{abstract}
The aim of this study was to evaluate histometric and biochemical properties of the thyroid gland of sheep supplemented with high doses of iodine. The study was conducted on ewes $(\mathrm{n}=$ $12)$ and gimmers $(n=12)$ of Sumava mountain sheep; each group was subdivided into two groups (group A and B) of six animals. Feed of group A was supplemented with $3 \mathrm{mg}$ iodine $/ \mathrm{kg}$ of dry matter; group B was given $5 \mathrm{mg}$ iodine $/ \mathrm{kg}$ dry matter. The iodine in feed mineral supplement was in the form of calcium iodide. The ewes were at first carrying, subsequently lambing, lactating and finally remained barren. The experiment ended after 11 months, when all animals were slaughtered and a sample of the thyroid gland was taken for histometric examination and determination of iodine content by modified colorimetric method. Prior to the slaughter, blood samples were collected for determination of thyroidal hormones and the thyroid-stimulating hormone in blood serum. Thyroid glands of sheep from group B showed higher thyroid weight, larger follicles, higher percentage of large follicles and lower follicular cells compared to groups A. Normal or lower content of triiodothyronine and thyroxine, lower content of their free fractions and bordering or elevated concentrations of thyroid-stimulating hormone were detected in blood serum of all four groups. This trend can signalize the tendency of lowering activity of the thyroid gland. The results of this long-term study show impacts of higher iodine intake on the structure and function of the thyroid gland in sheep.
\end{abstract}

Morphometric, thyroidal hormones, PCNA, epithelium, thyrocytes

The main function of the thyroid gland is the production of triiodothyronine $\left(\mathrm{T}_{3}\right)$ and thyroxine $\left(\mathrm{T}_{4}\right)$ hormones. Optimum intake of iodine influences function and structure of the thyroid. The height of the follicular cells, size of the follicles and amount and character of the colloid inside the follicles all depend on the activity of the thyroid (McGavin et al. 2001; Capen et al. 2006). Hypothyroidism caused by iodine insufficiency leads to higher production of thyroid-stimulating hormone (TSH) and subsequent proliferation of follicular cells and colloid depletion. Iodine in surplus, on the other hand, causes lowering of TSH production and accumulation of the colloid inside the follicles causing their growth. The lowered content of TSH further lowers the activity of thyrocytes and causes a decrease in epithelial cell height (Shan et al. 2009). The prolonged administration of large doses of iodine markedly reduces iodine trapping by the thyroid, thus causing antithyroidal or goitrogenic effects in many domestic and experimental animals (Radostits et al. 2000). Current importance of studying the activity of the thyroid gland in farm animals in connection with various amounts and forms of iodine in feed or varying iodine concentrations in the environment is shown in many recently published studies (Kursa et al. 2010; Baňoch et al. 2011; Dušová et al. 2012).

The aim of this study was to show the effect of long-term excessive iodine in feed on histometric and functional indicators in ewes and gimmers.

Address for correspondence:

Zdeněk Peksa

University of South Bohemia in České Budějovice

Faculty of Agriculture, Department of Veterinary Sciences and Quality of Products

Studentská 13, 37005 České Budějovice, Czech Republic 


\section{Materials and Methods}

Animals and experimental design

The study was conducted on ewes $(n=12)$ and gimmers, $(n=12)$ of Sumava mountain sheep; each group was subdivided into two groups (group A and B) of six animals. Both groups A were administered 3 mg iodine per $\mathrm{kg}$ dry matter DM feed dose; groups B were supplemented with $5 \mathrm{mg}$ iodine per $\mathrm{kg}$ DM (Table 1). The dose of $5 \mathrm{mg}$ per $\mathrm{kg}$ of $88 \%$ dry matter (DM) corresponds to the higher limit permitted in the norm (Commission Regulation of the EC No. 14/59/2005). The diet was composed of meadow hay

Table 1. Characteristics of experimental groups of sheep. $(1500 \mathrm{~g})$, oat groats $(270 \mathrm{~g})$ lucerne granules $(240 \mathrm{~g})$ and mineral supplement

\begin{tabular}{lccc}
\hline Group & $\begin{array}{c}\text { Age } \\
(\text { months })\end{array}$ & $\begin{array}{c}\text { Body weight } \\
(\mathrm{kg})\end{array}$ & $\begin{array}{c}\text { Iodine in feed } \\
(\mathrm{mg} \mathrm{I} / \mathrm{kg} \mathrm{DM})\end{array}$ \\
\hline Ewes A $(\mathrm{n}=6)$ & $76 \pm 4$ & $53.2 \pm 4.5$ & 3 \\
Ewes B $(\mathrm{n}=6)$ & $75 \pm 3$ & $56.3 \pm 4.8$ & 5 \\
Gimmers A $(\mathrm{n}=6)$ & $29 \pm 2$ & $59.2 \pm 4.6$ & 3 \\
Gimmers B $(\mathrm{n}=6)$ & $28 \pm 2$ & $58.4 \pm 5.4$ & 5 \\
\hline
\end{tabular}
$(9 \mathrm{~g})$. Iodine in mineral feed supplement was added in the form of calcium iodide $\left(\mathrm{CaI}_{2}\right)$. The ewes were at first carrying, subsequently lambing, lactating, and finally remained barren. The experimental period started in the first month of gestation. Environmental conditions (feed, housing conditions and temperatures) before and during experimentation were similar. The experiment was ended after 11 months when all the animals were slaughtered and a sample of their thyroid gland was taken for histometric examination and determination of iodine content. Prior to the slaughter, blood samples for determination of thyroidal hormones and the TSH in blood serum were collected. Ewes and gimmers were conducted under protocols approved by the Faculty of Agriculture, University of South Bohemia in České Budějovice and National Committees (Protocol No.2/08).

\section{Methods}

The whole thyroid gland was dissected and weighed. Samples for histological examination and samples for determining the iodine content were collected from the central part of each thyroid gland lobe. Samples were fixed in $10 \%$ neutral buffered formalin, embedded in paraffin wax, sectioned at $5 \mu \mathrm{m}$ thick slices and stained with haematoxylin and eosin. The measurements were conducted using Leica IM 500 Version 4.0 visual analysis program and Leica DC 320 camera in combination with Leica DM 2500 microscope. The size of 60 follicles (their length and width) and the height of 20 follicular cells inside each were determined from three fields of vision in different parts of the histological section. The examined follicles were classified into three categories by length (Jelín ek et al. 2003): large $(175.1-615.0 \mu \mathrm{m})$, medium sized $(80.1-175.0 \mu \mathrm{m})$ and small $(15.0-80.0 \mu \mathrm{m})$ follicles. The number of positive nuclei in thyrocytes in ten different fields of vision from different parts of the section was estimated as the indicator of proliferative activity of the thyroid follicular cells. Immunohistochemical reaction PCNA (proliferation cell nuclear antigen) was performed on every sample of the thyroid gland. Histological sections were deparaffined and the activity of endogenous peroxidase was blocked by $3 \%$ peroxide (10 min) and nonspecific binding sites were blocked (1\% bovine albumin for $5 \mathrm{~min})$. Monoclonal mouse anti-proliferation cell antigen/clon PC10 from Dako for PCNA detection was used. For visualization the detection system Dako EnVision ${ }^{\mathrm{TM}}$ was used.

Serum concentration of triiodthyronine (T3), tyroxine (T4), and their free fraction (FT3, FT4) were measured by radioimmunoassay (IMMUNOTECH a. s., Czech Republic); concentrations of thyroid-stimulating hormone (TSH) were determined by ELISA using commercially available kit (ELISA development, s.r.o., Czech Republic). The concentration of iodine in thyroid gland was determined by modified colorimetric methods according to Bednář et al. (1964).

The obtained results were evaluated by STATISTICA 7.0. (StatSoft, Inc.) with the help of ANOVA, regression and correlation analyses $(P<0.05)$.

\section{Results}

\section{Histometric characteristics of the thyroid gland}

Thyroid glands of sheep from group B supplemented with $5 \mathrm{mg}$ iodine $/ \mathrm{kg}$ DM showed higher thyroid weight, larger follicles, higher percentage of large follicles and lower follicular cells compared to group A supplemented with $3 \mathrm{mg}$ iodine $/ \mathrm{kg}$ DM (Table 2). When comparing the thyroid gland indicators of the two groups with the same iodine supplementation, the results showed that the thyroid glands of ewes had higher weight, higher iodine content, larger follicles, lower follicular cells, and 
Table 2. Thyroid gland indicators in sheep (ewes and gimmers) supplemented with iodine.

\begin{tabular}{lrrrr}
\hline \multirow{2}{*}{ Indicator } & \multicolumn{2}{c}{ Ewes } & \multicolumn{2}{c}{ Gimmers } \\
\cline { 2 - 5 } & \multicolumn{1}{c}{$\mathrm{A}$} & \multicolumn{1}{c}{$\mathrm{B}$} & $\mathrm{A}$ & $\mathrm{B}$ \\
\hline Weight $(\mathrm{g})$ & $7.5 \pm 4.2^{\mathrm{a}}$ & $9.67 \pm 0.47^{\mathrm{b}}$ & $3.74 \pm 0.37^{\mathrm{ab}}$ & $5.10 \pm 1.12^{\mathrm{ab}}$ \\
Iodine $(\mathrm{mg} / \mathrm{kg})$ & $1159.4 \pm 382.2$ & $1252.4 \pm 400.0$ & $396.1 \pm 154.0$ & $501.4 \pm 170.6$ \\
Large follicles $(\%)$ & $19.7 \pm 15.2^{\mathrm{c}}$ & $34.9 \pm 11.9^{\mathrm{d}}$ & $3.1 \pm 1.4^{\mathrm{cda}}$ & $24.4 \pm 2.2^{\mathrm{da}}$ \\
Medium follicles $(\%)$ & $51.0 \pm 16.5^{\mathrm{d}}$ & $42.6 \pm 9.6^{\mathrm{a}}$ & $39.7 \pm 8.3^{\mathrm{cd}}$ & $54.4 \pm 5.6^{\mathrm{ac}}$ \\
Small follicles $(\%)$ & $36.4 \pm 12.1^{\mathrm{c}}$ & $23.1 \pm 8.9^{\mathrm{a}}$ & $57.2 \pm 9.6^{\mathrm{ca}}$ & $21.3 \pm 7.7^{\mathrm{c}}$ \\
Length of follicles $(\mu \mathrm{m})$ & $132.9 \pm 28.4^{\mathrm{c}}$ & $146.8 \pm 24.7^{\mathrm{d}}$ & $83.0 \pm 11.1^{\mathrm{ca}}$ & $132.6 \pm 6.2^{\mathrm{da}}$ \\
Width of follicles $(\mu \mathrm{m})$ & $88.9 \pm 21.3^{\mathrm{c}}$ & $94.5 \pm 23.1^{\mathrm{b}}$ & $59.2 \pm 8.5^{\mathrm{abc}}$ & $93.7 \pm 2.3^{\mathrm{a}}$ \\
Height of epithelium $(\mu \mathrm{m})$ & $5.7 \pm 0.20^{\mathrm{a}}$ & $4.91 \pm 0.54^{\mathrm{c}}$ & $6.2 \pm 0.4^{\mathrm{ad}}$ & $5.4 \pm 0.1^{\mathrm{cd}}$ \\
Count of PCNA positive cells & $3.2 \pm 1.28^{\mathrm{ac}}$ & $4.8 \pm 1.49^{\mathrm{bc}}$ & $16.3 \pm 6.5^{\mathrm{abc}}$ & $6.3 \pm 1.7^{\mathrm{a}}$ \\
\hline
\end{tabular}

PCNA - proliferation cell nuclear antigen. Data are expressed as mean \pm SD. ${ }^{\mathrm{a}, \mathrm{b}} P<0.01$. ${ }^{\mathrm{c}, \mathrm{d}} P<0.05$

Table 3. Correlation between selected indicators in sheep (ewes and gimmers) supplemented with iodine.

\begin{tabular}{llc}
\hline Indicator & & Correlation coefficient \\
\hline Average epithelium height & Average follicle size & -0.60 \\
Count of PCNA positive cells & Percentage of large follicle & -0.47 \\
Count of PCNA positive cells & Percentage of small follicle & 0.45 \\
Percentage of large follicle & Thyroid weight & 0.73 \\
Iodine content in the thyroid gland & Thyroid weight & -0.35 \\
\hline
\end{tabular}

PCNA - proliferation cell nuclear antigen, $\mathrm{n}=24, P<0.05$

decreased proliferating activity (Table 2). Correlations between some indicators are shown in Table 3.

Thyroid follicles of ewes contained homogenous colloid mostly without resorptive vacuoles and the epithelial cells were mostly low cuboidal. In one thyroid gland specimen from ewes of group B, a small accumulation of lymphocytes without any trace of tissue alteration was found. Follicles of the gimmers contained mostly homogenous colloid with individual resorptive vacuoles and the epithelial cells were mostly cuboidal low to cuboidal. For all gimmers and several ewes, cysts of different sizes with cornified or uncornified squamous epithelium were present in different parts of the thyroid.

Biochemical properties of the thyroid gland

The mean content of T4 and T3 and their free fractions (FT4 and FT3) as well as the content of TSH was always higher or the same for gimmers compared to ewes with the same iodine supplementation (Table 4$)$. The most significant difference $(P<0.01)$ was found in the content of TSH between ewes and gimmers of group A and between ewes and gimmers of group B. The maximum concentration of TSH was measured for gimmers A and gimmers $\mathrm{B}$.

\section{Discussion}

The mean weight of thyroid gland in ewes of both groups in our study was higher than the reported weight of animals with normal histological structure (Kratochvíl 1998). We 
Table 4. The concentration of thyroidal hormones and thyroid-stimulating hormone in blood serum of sheep (ewes and gimmers) supplemented with iodine.

\begin{tabular}{lcccc}
\hline \multirow{2}{*}{ Indicator } & \multicolumn{2}{c}{ Ewes } & \multicolumn{2}{c}{ Gimmers } \\
\cline { 2 - 5 } & $\mathrm{A}$ & $\mathrm{B}$ & $\mathrm{A}$ & $\mathrm{B}$ \\
\hline T4 (nmol/1) & $60.42 \pm 12.89^{\mathrm{af}}$ & $63.08 \pm 11.03^{\mathrm{ec}}$ & $84.16 \pm 8.08^{\mathrm{ac}}$ & $82.80 \pm 11.38^{\mathrm{ef}}$ \\
T3 (nmol/l) & $2.55 \pm 0.37^{\mathrm{a}}$ & $2.14 \pm 0.34^{\mathrm{c}}$ & $2.50 \pm 0.03^{\mathrm{ac}}$ & $2.37 \pm 0.23$ \\
FT4 (pmol/l) & $13.67 \pm 1.81^{\mathrm{a}}$ & $13.12 \pm 2.04^{\mathrm{cd}}$ & $17.26 \pm 1.17^{\mathrm{ac}}$ & $16.50 \pm 0.99^{\mathrm{d}}$ \\
FT3 (pmol/l) & $3.29 \pm 0.35^{\mathrm{a}}$ & $2.91 \pm 0.46^{\mathrm{cd}}$ & $3.98 \pm 0.38^{\mathrm{ad}}$ & $4.66 \pm 0.74^{\mathrm{c}}$ \\
TSH (ng/ml) & $0.91 \pm 0.21^{\mathrm{ac}}$ & $0.97 \pm 0.22^{\mathrm{db}}$ & $2.78 \pm 1.01^{\mathrm{ad}}$ & $2.14 \pm 1.47^{\mathrm{cb}}$ \\
\hline
\end{tabular}

Data are expressed as mean $\pm \mathrm{SD} .{ }^{\mathrm{a}, \mathrm{b}, \mathrm{c}, \mathrm{d}} P<0.01 ;{ }^{\text {e,f }} P<0.05$

found higher iodine content in the gland of both groups of ewes compared to the two groups of gimmers. It can be connected to the longer accumulation time in the gland due to the age of the animals. They were exposed earlier to standard iodine doses or were burdened metabolically with pregnancy or nursing.

The histological picture of glands of both groups of ewes (especially for ewes of group B) in our study corresponds to lowered activity of the gland (Derycke et al. 1999; Jelínek et al. 2003). Furthermore, all indicators of lower activity were more pronounced in group B. When comparing histological pictures of ewes and gimmers with the same iodine supplementation, ewes showed signs of lower secretory activity of the thyroid according to McGavin et al. (2001).

When comparing ewes and gimmers, smaller mean size of follicles and generally higher follicular cells were demonstrated in ewes. According to Shan et al. (2009), the height of the follicular cells is an objective indicator of the thyroid gland activity. Lower proliferative activity of thyrocytes (presented in ewes by the level of PCNA) is according to Di Fulvio et al. (2000) a sign of lower activity of the thyroid gland. This fact was confirmed by correlation between count of PCNA positive cells and percentage of large or small follicles and other correlations.

When comparing the concentrations of T4, T3 FT3 and FT4 in both groups of ewes in our study, the concentration of free forms of hormones are lower according to Nazifi et al. (2008), Badiei et al. (2010) or Eshratkhah et al. (2011). Concentrations of hormones found in both groups of ewes corresponded to lowered activity of the thyroid gland as demonstrated by histological findings, too. Average values of TSH approached $1 \mathrm{ng} / \mathrm{ml}$ for both ewe groups in our study. In humans, this concentration would indicate euthyroid state with possible first signs of dysfunctions but so far without any clinical impact (Obregon et al. 2005). Concentrations of T3 and T4 in gimmers were similar to values mentioned in literature. Contents of FT3 and FT4 were in ewes lower that those given by for example Nazifi et al. (2008) or Badiei et al. (2010). Individual maximum values that over-exceeded $3.5 \mathrm{ng} / \mathrm{ml}$ in both groups of gimmers would imply latent hypothyroidism in humans. Higher values of TSH and simultaneous lower or normal concentrations of FT3 and FT4 would diagnostically indicate hypothyroidism or subclinical hypothyroidism (Ślebodzińsky 1994; Racek et al. 2006).

The presented data show the effects of the highest permitted iodine dose on histometrical and biochemical properties of the thyroid gland. The results demonstrate a decrease of thyroid function in animals with higher iodine intake. According to Ruffin et al. (2012), lower thyroid function negatively influences production and reproduction in sheep. For this reason they recommend optimization of iodine dosage in sheep at value $0.5-0.8 \mathrm{mg}$ I per kg dry matter (NRC, 2007). 


\section{Acknowledgements}

This work was supported by the project of the Grant Agency of the University of South Bohemia in České Budějovice (GAJU 011/2013/Z) and the grant of Ministry of Agriculture of the Czech Republic NAZV QH 81105.

\section{References}

Badiei K, Mostaghni K, Nikghadam P, Pourjafar M 2010: The effect of mercury on thyroid function in sheep. Int J Vet Res 4: 277-281

Baňoch T, Fajt Z, Kuta J, Kotrbáček V, Konečný R, Trávníček J, Svoboda M 2011: Utilisation of iodine from different sources by sows and their progeny. Neuroendocrinol Lett 32: 510-517

Bednár J, Röhling S, Vohnout S 1964: Contribution to the determination of protein iodine in bod serum (in Czech). Cesk Farm 13: 203-209

Capen CC 2006: Thyroid gland. In: Maxie MG (Ed.): Jubb, Kennedy and Palmer's pathology of domestic animals. Fifth edition, Elsevier, Philadelphia, pp. 379-406

Derycke G, Mabon N, Mandiki SNM, Bister JL, Wathelet JP, Marlier M, Paquay R 1999: Chemical changes and influences of rapeseed antinutritional factors on lamb physiology and performance: 1 . Animal performance and thyroid histology. Anim Feed Sci Techn 81: 81-91

Di Fulvio M, Coleoni AH, Pellizas CG, Masini-Repiso AM 2000: Tri-iodothyronine induces proliferation in vulture bovine thyroid cells: Evidence for the involvement of epidermal growth factor associated tyrosine kinase activity. J Endocrinol 166: 173-182

Dušová H, Trávníček J, Svoboda M, Baňoch T, Kroupová V, Peksa Z, Konečný R 2012: The impact of high iodine intake on thyroid function in ewes and lambs. Neuroendocrinol Lett 33: 517-524

Eshratkhah B, Sadaghian M, Eshratkhah S, Pourrabbi S, Najafian K 2010: Relationship between the blood thyroid hormones and lipid profile in Moghani sheep; influence of age and sex. Comp Clin Path 19: 15-20

Jelínek F, Krabačová I, Kroupová V 2003: Assessment of functional activity of the bovine thyroid gland using morphometry, and two markers of cellular proliferation. Acta Vet Brno 72: 651-662

Kaufmann S, Kursa J, Kroupová V, Rambeck WA 1998: Iodine in milk by supplementing feed: An additional strategy to erase iodine deficiency. Vet Med-Czech 43: 173-178

Kratochvíl P 1998: Morphological and functional changes of the thyroid gland in different breeding conditions (in Czech). Dissertation, University of South Bohemia in České Budějovice, 175.

Kursa J, Herzig I, Trávníček J, Illek J, Kroupová V, Fusková S 2010: Iodine and selenium contents in skeletal muscles of red deer (Cervus elaphus), roe deer (Capreolus capreolus) and wild boar (Sus scrofa) in the Czech Republic. Acta Vet Brno 79: 403-407

McGavin DM, Carlton WW, Zachary JF 2001: Thomson's special veterinary pathology. Mosby, St. Luis, 755 p.

Nazifi S, Seab M, Abangah E, Karimi T 2008: Studies on the relationship between thyroid hormones and some trace elements in the blood serum of Iranian fat-tailed sheep. Vet Arhiv 78: 159-165

NRC (National Research Council) 2007: Nutrient requirements of small ruminants (sheep, goats, cervids, and new world camelids). National academic press, Washington DC, $384 \mathrm{p}$.

Obregon MJ, Del Rey FE, De Escobar GM 2005: The effects of iodine deficiency on thyroid hormone deiodination. Thyroid 15: 917-929

Radostits O, Gay C, Blood D, Hinchcliff K, Arundel J, Jacobs D, Leslie K, Ikede R, McKenzie R, Bildfell D 2000 : Diseases caused by deficiencies of mineral nutrients. In: Radostits O, Gay C, Blood D, Hinchcliff K (Eds): A textbook of diseases of cattle, sheep, pigs, goats and horses. Saunders, London, pp. 1480-1514

Racek J, Eiselt J, Holeček V, Nekudová M, Pittrová H, Rušavý Z, Senft V, Šavlová M, Těšínský P, Verner M 2006 : Clinic Biochemistry (in Czech). Galén, Praha, 317 p.

Ruffin DC, Christman U, Pugh DG 2012: Endocrinology system. In: Pugh DG, Baird AN (Eds): Sheep and Goat Medicine. Second edition, Elsevier, Philadelphia, pp. 234-289

Shan Z, Teng W, Lai Y 2009: Experimental studies on the effect of excessive iodine supplementation on the thyroid tissue. In: Preedy VR, Burrow GN, Watson RR (Ed.): Comprehensive handbook of iodine. Academic Press, London, pp. 877-887Ślebodzińsky A 1994: The thyroid gland. In: Döcke F (Ed.): Veterinary Endocrinology (in German). Third Edition, Fischer Verlag Jena, Stuttgart, pp. 128-168 